Arenetra pallipes, n. sp.

Male-Length, Io-I $2 \mathrm{~mm}$. Black, with rufous legs. Head coarsely punctate; face and cheeks with very dense greyish pubescence; antennæ long and stout. Thorax more coarsely punctured, less pubescent, the pleuræ somewhat shining; all the coxæ and trochanters black, remainder of legs rufous, except posterior tibiæ, which are brownish; wings iridescent, sub-hyaline; stigma and nervures black. Abdomen finely sculptured, except the first segment, which is coarsely punctate at base and longitudinally aciculate at summit; lateral margins of segments $\mathbf{I}-4$ yellowish, apical margin of $2-6$ narrowly white.

Described from five $\delta$ specimens from Victoria, V. I. (Taylor), dated February, March and April, $\mathbf{1} 886$, and marked as "Very common, flying over garden at Cedar Hill."

\title{
COLEOPTERA TAKEN AT LAKE WORTH, FLORIDA.
}

BY JOHN HAMilton, M. D., ALlEGhenY, PA.

Lake Worth is an elongated bay connected with the ocean, two and one-half miles from its northern end, and separated from it by a narrow elevated strip of land, varying in width from two hundred to nine hundred yards. Its length is about 20 miles, while in width it averages about thirteen hundred yards. The country adjacent to the west shore is largely in its primitive state-white sand overgrown with Saw Palmetto, scrub live oak and many other shrubs and vines, with occasionally some pines. The flora of the strip between the lake and the ocean is designated the semi-tropical forest by Mr. Schwarz, who has largely developed the coleopterous fauna of South-eastern Florida.

The part of the lake and the ocean beach where this collection was made is that north from the inlet in about lat. $25^{\circ} 40^{\prime}$, long. $80^{\circ}$, this part of the coast being the most eastern point of Florida, and almost touched by the Gulf stream. The collecting was done from February I 8 th to April I 8 th, a season of the year when most insects have disappeared in these warm regions, as is well known, just as they do at the north during the same months. Insects were, perhaps, scarcer than usual on account of the dryness of the season, there having been no rain from December till my departure, and the temperature by night mostly $70^{\circ}$, and that of midday $84^{\circ}$. 
The whole number of species taken was 172 ; of these, eleven are undetermined, being either aleocharini or small things, only one of which is thought to be undescribed; of the others, 97 are very widely distributed; 40 (marked with a $\dagger$ ) extend westward in the Gulf States, some of these as far as Texas ; while only 25 (marked $*$ ), so far as known to the writer, have not occurred northward from Florida.

How many additional species exist in the territory collected over is conjectural, but certainly not more than $\mathrm{I}_{5}^{\circ}$, and these must be largely of species whose larvæ live in wood and fruits or seeds. The character of the soil, that of the flora and the long continued droughts militate against a coleopterous fauna prolific in species. This statement, however, applies only to this and similar localities.

$\dagger$ Cicindela tortuosa, Dej.

$\dagger$ media, Lec. marginata, Fab.

Pasimachus marginatus, Fab.

Scarites subterraneus, Fab.

Dyschirius var.* falciger, Lec.

Ardistomis obliquata, Putz.

Bembidium contractum, Say.

+ Tachys columbiensis, Limer. nanus, Gyll.

$\dagger$ Loxandrus agilis, Dej.

Diplochila major, Lec.

* Platynus var. floridanus, Lec. punctiformis, Say.

Galerita lecontei, Dej.

$\uparrow$ Tetragonoderus intersectus, Germ.

Lebia marginicollis, Dej.

Brachinus cordicollis, Dej.

Chlaenius fuscicornis, Dej. laticollis, Say.

Oodes americanus, Dej. lecontei, Chaud.

Agonoderus infuscatus, Dej.

$\uparrow$ Selenophorus fossulatus, Dej.

$\dagger$ Acupalpus rectangulus, Chaud.
Anisodactylus var. merula, Dej. nitidipennis, Lec.

Copelatus glyphicus, Say.

Thermonectes basilaris, Harr.

* Cybister olivierj, Crotch.

Tropisternus glaber, Hbst.

$\dagger$ Hydrocharis castus, Say.

Philhydrus var. † simplex, Lec.

+ Phœenonotum extriatum, Say.

? Homalota, 3 species.

Aleochara bimaculata, Grav. nitida, Grav.

Creophilus maxillosus, Linn.

Staphylinus prælongus, Mann.

Belonuchus formosus, Grav. var.*

Philonthus hepaticus, Er. alumnus, Er. micans, Grav.

Actobius cinerascens, Grav.

Cafius bistriatus, Er. •

Xantholinus, sp.

Lithocharis corticina.

Erchomus ventriculus, Say.

Bledius fumatus, Lec.

$\dagger$ punctatissimus, Lec. 
basalis, Lec.

Coccinella sanguinea, Linn.

Chilocorus bivulnerus, Muls.

Exochomus marginipennis, Lec.

$\dagger$ Contristatus, Muls.

Hyperaspis signata, Oliv.

Silvanus rectus, Lec.

* Hemipeplus marginipennis, Lec.

* Mycetophagidæ. -New gen. and spec.

Dermestes nubilus, Say.

Hister parallelus, Say.

* Chelioxenis xerobatis, Hubbard.

Saprinus pennsylvanicus, Payk.

$+\quad$ placidus, Er.

* ferrugineus, Mars.

sp. not determined.

† Plegaderus barbelini, Mars.

Carpophilus pallipennis, Say. mutillatus, Er.

Colastus semitectus, Say.

* Brachypeplus glaber, Lec.

Conotelus obscurus, Er.

† Epursea luteola, Er.

sp. indetermined.

Stelidota geminata, Say. octomaculata, Say. strigosa, Gyll.

Omosita colon, Linn.

* Smicrips hypocoproides, Reit.

Tenebrioides corticalis, Mels.

Monotoma fulvipes, Mels.

Heteroçerus var.-of substriatus, Mels.

$$
\text { collaris, Kies. }
$$

Cyphon variabilis, Thunb.

$\uparrow$ Lacon curtus, Lec.

Monocrepidius vespertinus, Fab. auritus, Hbst. $\dagger$ Ischiodontus ferreus, Lec.

$\dagger$ Orthostethus infuscatus, Germ.

Melanotus dubius, Lec.

sp. indetermined.

Buprestis lineata, Fab.

Chrysobothris floricola, Gory.

Brachys tessellata, Fab.

$\uparrow$ Pyropyga minuta, Lec.

$\dagger$ Photinus consanguineus, Lec.

Chatliognathus marginatus, Fab.

Collops tricolor, Say.

Necrobia rufipes, Fab.

Sitodrepa panicea, Linn.

Cis, sp.

+ Canthon nigricornis, Say.

Chœridium Lecontei, Harold.

Copris minutus, Drury.

* gopheri, Hubbard.

+ Phanæus igneus, MacL.

Onthophagus tuberculifrons, Harold.

* Aphodius troglodytes, Hubbard. Atænius strigatus, Say.

Trox suberosus, Fab. scaber, Linn

Strategus antaeus, Fab.

Cremastochilus harrisii, Kirby.

$\dagger$ Trichius texanus, Horn.

Elaphidion inerme, Newm. unicolor, Rand.

$\dagger$ Plectromerus dentipes, Oliv.

$\dagger$ Callichroma splendidum, Lec. Monohammus titillator, Fab.

* Leptostylus transversatus, Ches. Lema trilineata, Oliv.

Chlamys plicata, Fab.

+ Bassareus croceipennis, Lec.

Cryptocephalus binominis, Newm. 
Pachybrachys, sp.

* Metachroma floridanum, Crotch. Lina scripta, Fab. Haltica ignita, Ill.

+ Epitragus tomentosus, Lec.

$\dagger$ Polypleurus nitidus, Lec.

† Xylopinus saperdioides, Oliv. Opatrinus notus, Say.

Blapstinus metallicus, Fab.

+ Crypticus obsoletus, Say.

* Phaleria puncticeps, Lec.

$\dagger \quad$ longula, Lec.

$\dagger$ picipes, Say.

Diaperis hydni, Fab.

?* Tachyporus, n.s.

$\uparrow$ Platydema micans, Horn.

$\dagger$ Hymenorus densus, Lec.

* floridanus, Casey.

$\dagger$ Hyporhagus punctulatus, Thoms.

+ Oxacis thoracica, Fab.

* Mecynotarsus elegans, Lec.

$\dagger$ Formicomus scitulus, Lec.

Anthicus difficilis, Lec. $\dagger$ Anthicus pallens, Lec. vicinis $\mathrm{La} \cdot \uparrow$ ? vicinis var.

Attelabus analis, Ill.

* Pachnæus opalus, Oliv.

* distans, Horn.

* Artipus floridanus, Horn.

+ Listronotus setosus, Lec.

+ Macrops cryptops, Dietz.

Hylobius pales, Hbst.

Otidocephalus myrmex, Hbst.

* Notolomus basalis, Lec.

* Conotrachelus pusillus, Lec.

* Cryptorhynchus lutosus, Lec.

$\dagger \quad$ oblongus, Lec.

$\dagger$ Rhyncophorus cruentatus, Fab.

Sphenophorus cariosus, Oliv. sculptilis, Uhler. placidus, Say.

Cossonus corticola, Say. impressifrons, Bohm.

* Mesites rufipennis, Lec.

Xyleborus pubescens, Zimm.

Cicindela $-C$. tortuos $a$ may probably be found active at all seasons,

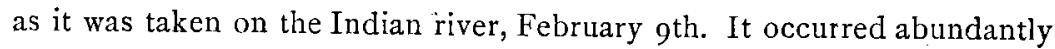
on the borders of the lake, and also on moist, sandy places in the hummock. C. marginata appeared February $2 \mathrm{Ist}$, and sparingly thereafter. C. media appeared on the beach March ist, and became very abundant onward.

Carabidce-Tachys columbiensis (undescribed) was seen March Ist, and became abundant on the lake shore, seemingly at home in salt water. Platynus floridanus was common on the coast after February 25 th, and also on land under all kinds of rubbish where there was moisture. Tetragonoderus intersectus and Selenophorus stigmosus were taken in the garden patches under the dry fallen leaves of vegetables-as cabbage,

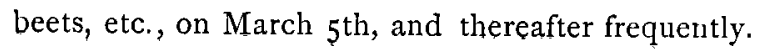


Dytiscidce-Hydrophilidee.-The species listed were taken alive on the ocean side of the lake, and, with one exception, had probably fallen into it during a nocturnal flight from some fresh water lake on the main land. However, Philhydrus simplex was quite abundant under stones and sticks on the shores of the lake, and the night of the roth of March being damp and sultry, a flight occurred, many coming into the house to the light. This form, though only .09 to. I $\mathrm{r}$ inch in length, is united with the northern ochraceus. Gyrinide were seen in abundance in a small lake on the main land.

Staphylinidce-Belonuchus formosus, var. This variety was very abundant at all times in rotting oranges and under damp rubbish; it differs from the typical form in being altogether rufous, except the last two abdominal segments, black. No intermediate forms have been met with, and Mr. Schwarz states it occurs abundantly over all Florida.

Tachyporus, sp.-Two examples were taken under pine bark, greatly resembling my examples of $T$. scitulus from Sweden ; the thorax and elytra are identical in coloration, but are not perceptibly punctured when viewed with a lens; the abdomen is more finely margined, and the length is only .06 to .07 inch. Bledius punctatissimus, and B. basalis.-The latter inhabits the wet sand bordering the lake in countless multitudes, and with it the former, bit in much less abundance. B. fumatus was not seen till April ist, and afterwards rarely. One of the types of this species was from Southern California.

Brachypeplus glaber--Five examples of this curious and still rare beetle were taken under the bark of a dead, standing pine, with Cossonus impressifrons. Previously I had one example taken near St. Augustine, and the types were from Enterprise, Florida; according to Mr. Schwarz, no others are known in North American collections.

Mycetophagidce-Belonging to this family several examples were taken in April, of what may, perhaps, be new either generically or specifically, or both. They were sheltering in the folds of Palmetto leaves, on the blossoms of which Mr. Schwarz took them abundantly, both at Lake Worth, and also at Biscayne Bay, and also the larvæ under the bark of various trees; and he also states that it occurs in the West Indies, in Costa Rica, and was taken at the Chicago Exposition, in dried. fruits (or seeds?) from Central America. 
Monotoma fulvipes occurred abundantly in rotting oranges, with Smicrips hypocoproides and several small Nitidulidce.

Scarabceide-Copris gopheri, Aphodiust roglodytes and the Histeride Chelioxenis xerobatis were taken $\mathrm{I} 2$ or $\mathrm{I} 5$ feet under ground, at a depth of about five feet, with the great sand-digging tortoise, Gopherus poly. phemus. Cremastochilus Harrisii.-An example was taken April 4 th, with a large ant. Trichius texanus occurred abundantly in the blossoms of Magnolia, April soth.

Cerambycidie-Plectromerus dentipes was taken, March 5 th, by bushbeating, and the imago, pupæ and larvæ were found abundantly in the dead branches of a species of Schrankia, which produces the so-called "lucky bean," and which is popularly termed "wait a bit," which one will perforce certainly do on coming in contact with its retrose thorns. Callichroma splendidum.-Though I did not take this species, examples were seen which had occurred. These had probably bred in some of the swamps some distance inland.

Tenebrionida--Opatrinus notus was at all times excessively abundant; harbouring under boards, etc., on the dry sand. It breeds around the stem of the cabbage Palmetto, among the bases of the fallen leaves: Crypticus obsoletus was quite abundant in the same situations, and with it Platydema nitens, though less numerous. Phaleria puncticeps was rare on the ocean beach, while $P$. longula and picipes appeared about March 1 st, and gradually became very abundant.

Hyporhagus hunctatus-Several examples were taken under the bark of dead seagrape (cocolobus), where they seemed to be in hibernation, though exposed to the sun with a midday temperature of $85^{\circ}$.

Anthicidce-Mecynotarsus elegans was abundant in cultivated places on spots of sand hot enough to blister. It is difficult to capture on account of its swift, intricate gyrations. A minute ant inhabits the same places, and goes through the same movements. It may be a question whether the ant has learned these motions from the beetle or the beetle from the ant, but the advantage in one direction seems to be on the part of the beetle, as it is usually safe from beetle hunters till accidentally discovered. Formicomus scitulus was also abundant under boards and the dead leaves of garden vegetables where there was sand. Anthicus, sp:: Several examples were taken under dry cut grass with Silvanus rectus. 
It is very close to the California confinis, but may be distinguished by the punctuation being generally finer. It may be a race of vicinus without banded elytra and smaller than the type.

Rhyncophorce-Artipus floridanus, popularly known as the "rose bug," does not seem to hibernate at this season, if indeed it ever does; it exists in great numbers and does as much mischief as its northern namesake; though polyphagous, it seems to have a special fondness for citrus, particularly the lime, destroying the blossoms and young fruit, and likewise nipping the margins of the leaves, which become white, giving the tree a stunted, frosted appearance. On the main land this beetle feeds on the leaves of the live oak, and of such, many are of a brilliant verdigris. green colour, instead of the creamy white of those raised on citrus. Macrops cryptops and Listronotus setosus are found abundantly in the flowers of Sagittaria. Notolomus basalis abound from the middle of February till the various Palms are out of bloom. Cryptorhynchus lutosus breeds abundantly in the disks (rods) of an abnormal leguminous shrub, Ecastophyllum brownei. The most of the fruit ripens and falls from the bush before February, at which time the beetles escape, but the few belated disks found ripening, in nearly every instance contained a beetle in some stage. The determination of both beetle and plant is due to Mr. Schwarz, who had previously taken this insect at Biscayne Bay.

Mesites rufipennis-One example, $\delta$, was taken on the beach; the antennæe are inserted about the middle of the beak, which is coarsely punctured to the tip, and has the usual frontal fovea and deep groove extending in front of the insertion of the antennæ; on its under side is a deep broad groove extending from the tip to the gula. This species resembles closely immature examples of $M$. subcylindricus, but is more depressed, and the elytral intervals are less convex and more finely punctulate.

Scolytide-The examination of dead hardwood indicated that several species of this family were abundant in their season. The larvæ of one small species was observed in almost incredible numbers boring outwards in the bark of Ficus aurea, preparatory to pupation; they were so close together that the surface of the back could scarcely be seen. They were white, about .06 inch long, and too numerous to make traceable galleries under the bark, not being wood borers. 